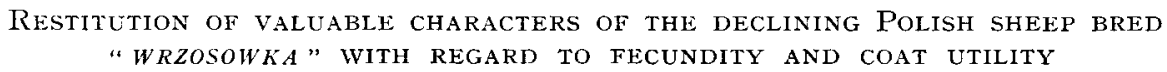

W. Nawara. - Institute of Zootechnics, Sheep Breeding Department Krakow, Poland.

The report discusses the investigations upon some valuable properties of the declining old Polish sheep breed Wrzósowka concerning fecundity and sheepskin utility.

Before 50 years the Wrzosóreha breed composed $\mathbf{I} / 4$ of the sheep population of the NorthEast region of Poland and was characterized by the following useful parameters: live weight of single born lambs amounted to $I, 8 \mathrm{~kg}$, of twin born lambs to 0,9 at weaning to $14,4 \mathrm{~kg}$ and in ripe age to $34,6 \mathrm{~kg}$. The fecundity amounted to I $50-184$ per cent at 22 per cent of single born lambs, 72 per cent of twin born lambs, 52 per cent of triplets and 0,8 per cent of quadruplets. The yield of greasy wool of grey colour in the tint from brown to fair in a yearly regrowth amounted to $I, 3 \mathrm{~kg}$ at a staple length of $9,5 \mathrm{~cm}$ after a regrowth of $1 / 2$ year. The anatomic composition of the fibres in the coat amounted to about 70 per cent down fibres and 30 per cent medullated fibres, shorter than the down fibres.

At present observations in the breeding methods are carried out on 477 sheep in the Experimental Station of the Institute of Zootechnics at Czechnica. The data obtained for a period of 5 years (I97I-I975) in comparison with those obtained before 50 years show an increase of live weights of about 1 5-25 per cent, however a distinct fecundity decrease of about 25 to 30 per cent took place at a smaller intensity of about 50 per cent twin-born lambs and triplets. Nevertheless the results obtained till now indicate the possibility of fecundity restitution, improvement of the quality of coat assigned to artistic tissues and of the pelt to the production of sheepskins, at a simultaneous maintenance of a high vitality and immunity of this breed from new diseases. A further adequate mating of these animals at a comperatively high percentage of rams in relation to the ewes will permit to maintain in the breed examined its different properties without parallel not only in other breeds and breeding varieties in Poland but also - as may be supposed - in the majority of old European breeds.

\title{
The DeVelopment OF A PROLific BREed OF SHEEP
}

\section{J. B. Owen. - School of Agriculture, Old Aberdeen ABg rUD, Scotland.}

The paper describes the development, over a ten year period, of a new breed of sheep the Cambridge — designed to combine high prolificacy with other attributes of British breeds. The development was based on a initial screening of 12 British sheep breeds on the basis of individual ewe prolificacy and the incorporation of a small proportion of genes from the Finnsheep breed. Following the initial screening the foundation population has been improved by within population selection largely based on the selection of ram lambs on their dam's prolificacy and the culling of ewes on their own early performance. Generation length has been minimised by the use of rams only as ram lambs and of severe culling of ewes at three years of age.

The breed is being further tested and multiplied by the cooperation of several commercial breeders and trials are in progress to assess the value of the breed as sires of crossbred ewes for commercial slaughter lamb production. Results so far indicate that a mature pure bred ewe performance target of almost 3 lambs born per ewe lambing is being achieved in practice and that this should lead to a substantial increase in lambs sold per ewe and overall profit in crossbred ewes sired by rams of this breed.

\section{ERGEbNisse DER ZERLEGUNG VON LAMMERSChLACHTKORPERN MIT VERSCHIEDENEN ANTEILEN FINNISCHER LANDRASSE}

T. Popp, P. Terzis und R. Wassmuth. - Institut für Tierzucht und Hanstiergenetik der Justus Liebig-Universität Giessen D-Giessen, Deutschland.

In den Jahren 1975 und 1976 wurden insgesamt 167 Schlachtkörper von Lämmern mit unterschiedlichem Finnanteil in Fleisch, Fett und Knochen zerlegt. I 9 Lämmer wurden in Einzelmast mit pelletiertem Kraftfutter bei unterschiedlichem Mastendgewicht und $4^{8}$ Lämmer nach Gruppenmast im Alter von I 25 Tagen geschlachtet.

Die Einbeziehung der finnischen Landrasse in Kreuzungsprogramme führt zu Veränderungen im Schlachtkörperwert. Schlachtköıper und die Keulen nehmen gegenüber schwarzköpfigen 
Fleischschafen an Länge zu und sind weniger voll ausgebildet. Vor allem bei Merkmalen der Verfettung wirkt sich der steigende Finnanteil aus. Sowohl der Körperfettanteil als auch die Menge des Nierenfettes zeigen eine deutliche Erhöhung.

Der teilweise Ersatz von Finnschafgenen durch Milchschafgene wirkt sich bei diesen Merkmalen positiv aus.

\section{Productivity of FINNISH LANDRACE $\times$ DORSET HORN EWES}

J. J. Robinson, C. Fraser, J. C. Gill and I. McHattie. - The Rowett Research Institute Bucksburn, Aberdeen, Scotland.

Results are presented for the breeding performance of Finn $\times$ Dorset Horn ewe lambs or ewes in a once per year breeding system. Conception rate at a mean age of $238 \pm 9.4$ days was 91.7 per cent and mean litter size I.52. Corresponding values for $294 \pm$ II.4 days were 94.3 per cent and 1.70. An interaction between time of year of birth and onset of puberty was observed, with ewe lambs boin as late as November showing behavioural oestrus before the end of the breeding season. Ewes bred once per year had a mean litter size of 2.34.

Results are also given for a frequent breeding experiment in which two flocks each of 48 ewes were repeatedly subjected to artificial daylength regimes, weaned after one month of lactation and synchronised in cestrus by using a synthetic progestagen. Total annual production was 3.5 lambs per ewe.

The amounts and patter $n$ of food intake during the reproductive cycle required to achieve this level of production are presented.

The results of experiments designed to show whether the increased frequency of breeding and high level of production achieved under conditions of artificial daylength control could be achieved under natural conditions are presented. In these studies a conception rate of 92.8 per cent was obtained in ewes bred during the normal period of anoestrous using 400 I.U. of pregnant mares serum gonadotrophin at pessary withdrawal.

Mean daily lamb growth rate and estimated milk yield in twin bearing ewes given ad libitum a diet containing to MJ metabolizable energy per $\mathrm{kg}$ was $0.29 \pm 0.05$ and $2.93 \pm 0.5 \mathrm{I} \mathrm{kg}$ respectively.

\section{LE CROISEMENT ROMANOV ET FINNOIS SUR L'ARAGONAISE : RÉSULTATS PRÉLIMINAIRES D'ENGRAISSEMENT ET DE REPRODUCTION}

M. Valls Ortiz, Y. Cognie, M. D. Valdemoro et J. Hallauer. - C.R.I.D.A.-o3, I.N.I.A. Apartado 202, Zaragoza, España.

Les performances des $\mathrm{F}_{\mathbf{1}}$ obtenues avec les races Romanov et Finnoise sur un troupeau de too brebis Aragonaise Rasa (p. v. 45 kg), sont étudiées depuis I974, dans le cadıe des essais d'utilisation de ces races prolifiques en milieu Méditerranéen.

D'après les résultats constatés, il semblerait que l'utilisation du Romanov ou de Finnois sur une race rustique de format moyen permet une amélioration de la croissance par rapport à la race 1 ustique. Dans le cas présent, l'avantage a été de l'ordra de 15-20 p. Ioo pour le RO $\times$ RA et de Io-I 5 p. Ioo pour le FI $\times$ RA. Le croisement dans ces conditions, bien que sans améliorer natablement l'aspect des carcasses, permettrait l'obtention de carcasses plus lourdes pour un même degré de maturité.

Che les femelles, la précocité sexuelle (un mois d'avance au r er œstrus) et surtout le taux d'ovulation, sont nettement améliorés par effet du croisement, avec un léger avantage des crossées RO sur les croisées FI. Le taux d'ovulation moyen au cours d'une saison à l'âge de 2 ans, a été de $\mathrm{I}, 73, \mathrm{I}, 60, \mathrm{I}, 06$ respectivement pour les croisées RO, FI et les RA pures.

La saison sexuelle bien que de durée à peu près similaire pour les trois génotypes, semble pourtant, commencer et finir plus tard chez les croisées que chez les Rasa.

\section{REPRODUCTIVE EFFICIENCY OF ICELAND SHEEP \\ I. PUBerty AND EARLy REPRODUCTIVE PERFormance}

O. R. Dyrmundsson. - The Agricultural College Hvanneyri, Hvanneyri, Iceland.

Lambs of the Iceland breed of sheep are found to be early maturing. The level of reproductive efficiency in the flock is raised by breeding from ewe lambs and by using ram lambs for mating. The reproductive potential of the lamb is increasingly being realized by farmers in Iceland. 